\title{
The Influence of Organizational Commitment, Job Stress, and Work Motivation on Job Satisfaction (A Study at PT Matsuo Precision Indonesia's Injection Molding Deptin Cikarang)
}

\author{
Jamaliah Said', Retno Purwani Setyaningrum ${ }^{2}$, Arief Teguh Nugroho ${ }^{3}$, Sinta \\ Yulianingsih $^{4}$ \\ Universiti Teknologi MARA ${ }^{1}$, Universitas Pelita Bangsa ${ }^{2,3,4}$ \\ jamaliah533@uitm.edu.my ${ }^{1}$,retno_purwani_setyaningrum29@yahoo.com², \\ dosenarief@pelitabangsa.ac.id $\mathrm{d}^{3}$, sintayulianingsih336@gmail.com ${ }^{4}$
}

\begin{abstract}
Employee development needs to be accompanied by increased employee satisfaction in carrying out duties and jobs. Employees who have job satisfaction will show positive attitudes and emotions so that they are able to work well. Employee job satisfaction is determined by the factors of organizational commitment, job stress and work motivation. The purpose of this study is to determine the influence of organizational commitment, job stress and work motivation on job satisfaction of the employees of PT. Matsuo Precision Indonesia. This research used quantitative method, with multiple linear regression analysis method. The population in this study were 61 respondents. Sampling in this study was selected using saturated sampling techniques. The testing using the SPSS V24 program shows that organizational commitment had no significant effect on job satisfaction, based on the results of the T test which obtained a calculated $\mathrm{T}$ value of $1.065<\mathrm{T}$ table of 2.002 with a Sig. level 0.212 $>0.05$; job stress had a positive and significant effect on job satisfaction, based on the results of the $\mathrm{T}$ test which obtained a value of $2.041>\mathrm{T}$ table of 2.002 with the a Sig. level $0.046<0.05$; and work motivation had a positive and significant effect on job satisfaction, based on the results of the $\mathrm{T}$ test which obtained a value of $7.404>\mathrm{T}$ table of 2.002 with a Sig. Level $0.000<0.05$. Based on the calculation of the value of F count $22.863>\mathrm{F}$ table 2.53 and the value of Sig. equal to $0.000<0.05$, it can be concluded that organizational commitment, job stress and work motivation altogether have a significant influence on job satisfaction at PT. Matsuo Precision Indonesia.
\end{abstract}

Keywords: Organizational Commitment, Job stress, Work Motivation, Job Satisfaction

\section{Introduction}

In this globalization era, companies must be able to survive given that business competition is getting tougher. Companies must have good management and must be able to improve the quality of its human resources. Quality resources are needed in today's highly 
developed business world so that companies can achieve their goals well and obtain maximum business results.

High job satisfaction is expected to make employees more loyal to the organization, more motivated to work, feel happy at work, and finally increase productivity. Disgruntled employees tend to shy away from duties and responsibilities, which will disrupt the process of achieving organizational goals. Disgruntled employees often stay away from a job and are more likely to leave. Satisfied employees have better health, longer life, and job satisfaction will be taken out of the organization.

Nowadays companies see human resources as an important thing to pay attention to. For both public and business organizations, humans are the main resource because humans are the ones that move other resources. In achieving organizational or company goals, there are many efforts that can be made. One such effort is to pay attention to the work attitude of human resources, which in this case is aimed at employees.

PT. Matsuo Precision Indonesia is an automotive company engaged in car electrical parts. In this company, there are several processes carried out such as injection molding, press and stamping for local and export support. This company is located at the Greenland International Industrial Center (GIIC) Industrial Zone, Blok AE No. 3 Kota Deltamas, Nagasari Village, SerangBaru District, Bekasi. Based on the results of observations and interviews conducted by the researchers, the researchers found out that the job satisfaction of employees of PT. Matsuo Precision Indonesia was considered low.

From the phenomena that occured within the company, job satisfaction was one of the things that the company really cared about. This has been proven in the last three years of research. The following is the secondary data from the results of job satisfaction research that the researchers got:

Table 1. Job Satisfaction

\begin{tabular}{|c|c|c|c|c|}
\hline Dimension & \multicolumn{3}{|c|}{ Achievement } & Std \\
\hline Salary & 2017 & 2018 & 2019 & \\
\hline Duty & $16 \%$ & $15 \%$ & $11 \%$ & $50 \%$ \\
\hline Facility & $35 \%$ & $45 \%$ & $33 \%$ & $50 \%$ \\
\hline Management Treatment & $37 \%$ & $47 \%$ & $38 \%$ & $50 \%$ \\
\hline Teamwork & $23 \%$ & $25 \%$ & $22 \%$ & $50 \%$ \\
\hline Career Development & $50 \%$ & $56 \%$ & $50 \%$ & $50 \%$ \\
\hline Salary & $22 \%$ & $24 \%$ & $23 \%$ & $50 \%$ \\
\hline Average & $31 \%$ & $35 \%$ & $30 \%$ & $50 \%$ \\
\hline
\end{tabular}

Organizational commitment has an important role for a company. The existence of organizational commitment makes an employee do the job happily. [10] states that organizational commitment does not have a significant influence on employee job satisfaction. Organizational commitment has an important role for a company. The existence of organizational commitment makes an employee do the job happily. If an employee has organizational commitment, the employee will be more satisfied and the company can increase employee job satisfaction. [2] in his research shows that organizational commitment has a positive and significant influence on job satisfaction. The same statement is also found in research [3] where the organizational commitment variable is proven to have a positive and significant effect on the job satisfaction variable.

Job stress can help or damage employee job satisfaction, depending on how intense the stress level is. [4] shows that job stress has a significant and negative effect on job satisfaction. 
Job stress can be defined as a condition in which a person experiences pressure or tension in his work and work environment, so that the person responds negatively and feels burdened in completing his obligations. Feelings of stress at work can prevent a person from completing their work so this condition needs to be addressed early before this feeling of stress occurs. [5] states that job stress has a significant and negative effect on job satisfaction. Job stress, from the respondents' responses to the five dimensions of job stress (excessive workload, time pressure, authority to carry out responsibilities, differences between organizational and employee values, and frustration) show that overall job stress experienced by employees is in the category "high". This is consistent with the research from [6] which states that job stress has a negative and significant influence on employee job satisfaction.

Work motivation according to Maslow's theory in [1] can be measured by several things such as physiology, safety needs, social needs, reward needs, and self-actualization needs. Providing motivation for employees at work is an important factor in the organization. By being motivated and encouraged, employees will be more enthusiastic about doing work so that they can achieve good results. [1] shows that motivation partially has a significant positive influence on job satisfaction. [7] also states the same statement namely motivation has a significant influence on job satisfaction. What's more, research [8] shows that work motivation has a significant influence on job satisfaction. This means that high motivation will be able to increase job satisfaction. Job satisfaction is the result of employee perceptions or assessments of whether or not a job is good based on things considered important by employees [9]. For this reason, serious attention is required to increase maximum employee job satisfaction.

\section{Research Method}

The analysis used in this research was descriptive and verification analysis, namely multiple linear regression. Before conducting the actual multiple linear regression analysis, the researchers conducted a requirements analysis test, namely the classical assumption test. The classical assumption test was used to prove that the multiple linear regression equation model was econometrically acceptable because it met the BLUE (Best Linear Unavailable Estimator) estimation, which means the estimation was unbiased, linear and consistent. The assumption test consisted of normality, linearity, multicollinearity, autocorrelation, and heteroscedasticitytests (Mulyanto and Wulandari, 2010: 181). After the assumption test was fulfilled, multiple linear regression analysis was carried out. The main results of the analysis were the correlation coefficient R, the coefficient of determination R Square (R2), and the multiple linear regression equation model: $\mathrm{Y}=\mathrm{a}+\mathrm{b} 1 \mathrm{X} 1+\mathrm{b} 2 \mathrm{X} 2+\mathrm{b} 3 \mathrm{X} 3$ where $\mathrm{X} 1=$ organizational commitment, $\mathrm{X} 2=$ job stress, $\mathrm{X} 3=$ work motivation, $\mathrm{Y}=$ employee job satisfaction, $\mathrm{a}=$ constant, $\mathrm{b} 1=$ organizational commitment regression coefficient, $\mathrm{b} 2=$ job stress regression coefficient, $\mathrm{b} 3=$ work motivation regression coefficient. 


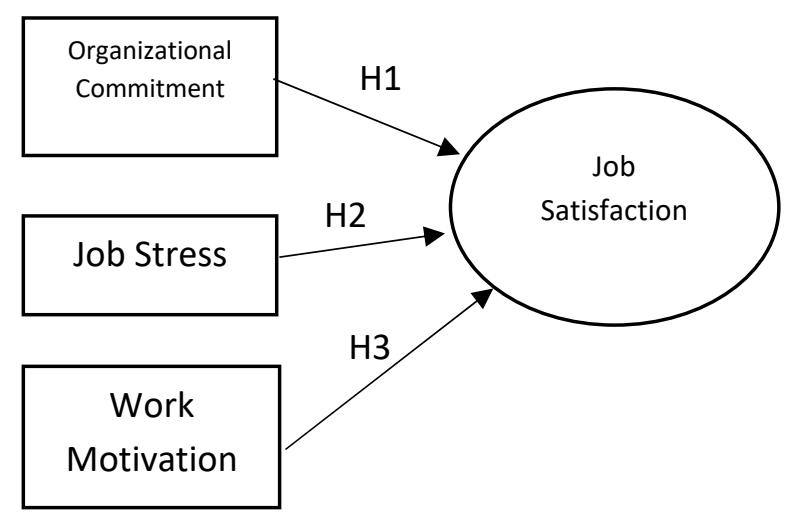

Fig.1. Regression equation model

The research on the influence of organizational commitment, job stress and work motivation on employee job satisfaction used a quantitative approach, namely research in the form of numbers and using statistics analysis. Quantitative research can be defined as a research method based on the philosophy of positivism, which is used to conduct a research on a particular population or sample. The sampling technique is generally carried out randomly, data collection uses research instruments, and data analysis is quantitative / statistical in nature with the aim of testing predetermined hypotheses. This research was conducted at PT. Matsuo Precision Indonesia, which is located at the Greenland International Industrial Center (GIIC) Industrial Zone, Blok AE No. 3 Kota Deltamas, Nagasari Village, SerangBaru District, Bekasi.

The population of this study were all employees of PT. Matsuo Precision Indonesia in injection molding department with a total number of 61 people consisting of injection operators and maintenance. This study used the Probability Sampling method or saturated sample, where the entire population as many as 61 people was sampled. This research used quantitative method with multiple linear regression analysis method and with a test using the SPSS V24 program. The purpose of this study is to determine the influence of organizational commitment, job stress and work motivation on job satisfaction of employees of PT. Matsuo Precision Indonesia.

\section{Discussion}

The assessment of research variables was carried out using a questionnaire developed from the indicators for each research variable. From the results of the validity test of each research variable, it could be seen that all question items for each variable were valid. From the reliability test, it could be seen that all questions considered valid on each research variable were able to prove their reliability. Since the questionnaire was valid and reliable, the research questionnaire was a reliable tool for measuring each research variable.

Based on the results of instrument testing and the results of data analysis and the results of observations made, the influence of Organizational Commitment, Job Stress, and Work Motivation on Job Satisfaction can be shown and explained as follows: 
Table 2. Hypothesis Description

\begin{tabular}{llll}
\hline & \multicolumn{1}{c}{ Hypothesis Description } & T Value & Conclusion \\
\hline H1 & $\begin{array}{l}\text { Organizational Commitment has a positive influence } \\
\text { on Job Satisfaction }\end{array}$ & 1.065 & Rejected \\
H2 & $\begin{array}{l}\text { Job Stress has a positive influence on Job Satisfaction } \\
\text { H3 }\end{array}$ & $\begin{array}{l}\text { Work Motivation has a positive influence on Job } 7.041 \\
\text { Satisfaction }\end{array}$ & $\begin{array}{l}\text { Accepted } \\
\text { Accepted }\end{array}$ \\
H4 & $\begin{array}{l}\text { Organizational Commitment, Job Stress, and Work } 22.863 \\
\text { Motivation altogether have a positive influence on Job } \\
\text { Satisfaction }\end{array}$ & Accepted \\
\hline
\end{tabular}

\subsection{The Influence of Organizational Commitment Variable on Job Satisfaction}

Based on the testing results carried out on the influence of Organizational Commitment on Job Satisfaction, the researchers obtained an $\mathrm{R}$ value of 0.546 . This shows that there was a direct influence between the independent variable and the dependent variable so that the percentage obtained was $54.6 \%$, while the other $45.4 \%$ was influenced by other factors outside the organizational commitment variable. Meanwhile, based on the testing results on the test, the researchers obtained $t$ count of 1.065 with a significance level of 0.292 , which means $t$ count $<\mathrm{t}$ table and Sig. $>0.05$, which means that $\mathrm{H} 0$ was accepted and Hal was rejected. The results of this study indicate that there was no significant influence between the variables of Organizational Commitment on Job Satisfaction at PT Matsuo Precision Indonesia. This is supported by the answers from respondents on the questions in the qualitative questionnaire showing that the current organizational commitment made employees had more sense of belonging to the organization. However, there were several respondents who answered that the current organizational commitment did not make employees had a sense of belonging to the organization. The results of this study are consistent with previous research conducted by [10] which reveales that there is no significant influence between organizational commitment and job satisfaction.

\subsection{The Influence of Job Stress Variable on Job Satisfaction}

Based on the testing results carried out on the influence of Job Stress on Job Satisfaction, the researchers obtained an $\mathrm{R}$ value of 0.546 . This shows that there was a direct influence between the independent variables so that the percentage obtained was $54.6 \%$, while the other $45.6 \%$ was influenced by other factors outside the job stress variable. Meanwhile, based on the testing results on the $t$ test, the researchers obtained $t$ count of 2.041 with a significance level of 0.046 , which means $t$ count $>\mathrm{t}$ table and Sig. $<0.05$, which means that $\mathrm{H} 0$ was rejected and Ha2 was accepted. The results of this study indicate that there was a positive and significant influence of Job Stress variable on Job Satisfaction at PT Matsuo Precision Indonesia. This is supported by the answers from respondents on the questions in the qualitative questionnaire showing that the targets and work demands set by the company did not overburden the employees so that it minimized the occurence of job stress. However, there were several respondents who answered that there were a lot of targets and work demands set by the company that overburden them so that it triggered the occurence of job stress. The results of this study are consistent with previous research conducted by [4] which reveales that there is positive and significant influence between job stress and job satisfaction. 


\subsection{The Influence of Work Motivation Variable on Job Satisfaction}

Based on the testing results carried out on the influence of Work Motivation on Job Satisfaction, the researchers obtained an $\mathrm{R}$ value of 0.546 . This shows that there was a direct influence between independent variables and dependent variable so that the percentage obtained was $54.6 \%$, while the other $45.6 \%$ was influenced by other factors outside the work motivation variable. Meanwhile, based on the testing results on the t test, the researchers obtained $t$ count of 7.404 with a significance level of 0.000 , which means $t$ count $>t$ table and Sig. $<0.05$, which means that $\mathrm{H} 0$ was rejected and Ha3 was accepted. The results of this study indicate that there was a positive and significant influence of Work Motivation variable on Job Satisfaction variable at PT Matsuo Precision Indonesia. This is supported by the answers from respondents on the questions in the qualitative questionnaire showing that the current motivation made the employees more creative in developing thier ideas. However, there were several respondents who answered that the current motivation did not make the employees self-motivated. The results of this study are consistent with previous research conducted by [1] which reveales that there is positive and significant influence between work motivation and job satisfaction.

\section{Conclusion}

This research was conducted to determine the influence of organizational commitment, job stress, and work motivation on job satisfaction. Based on the research results and discussion, it can be concluded as follows:

a) Organizational commitment had no significant influence on job satisfaction of the employees of PT. Matsuo Precision Indonesia. This shows that organizational commitment gave an effective contribution of $1.69 \%$ and a relative contribution of $3.09 \%$ to job satisfaction. This shows that the influence was low. This low influence was supported by a good organizational commitment that was considered less than fulfilling employees' commitment to their personal. This was supported by the answers from several employees on the questions distributed through qualitative questionnaires which showed that employees did not have a sense of belonging to the organization and to stay with the organization was their current desired need. The better the organizational commitment was built, the higher the job satisfaction of employees at PT. Matsuo Precision Indonesia.

b) Job stress had a positive and significant influence on job satisfaction of the employees of PT. Matsuo Precision Indonesia. This shows that job stress gave an effective contribution of $5.28 \%$ and a relative contribution of $9.67 \%$ to job satisfaction. This shows that the influence was low. This low influence was supported by the pressure at work that triggered the occurence of job stress on the employees' personal. This was supported by the answers from several employees on the questions distributed through qualitative questionnaires which showed that the targets set by the company was often burdensome and superiors always gave harsh warnings to employees who made work mistakes and that made the employees depressed or stressed at work. The smaller the level of work stress that was in the company, the higher the employee satisfaction at PT. Matsuo Precision Indonesia was. 
c) Work motivation had a positive and significant influence on job satisfaction of the employees of PT. Matsuo Precision Indonesia. This shows that work motivation gave an effective contribution of $47.64 \%$ and a relative contribution of $87.26 \%$ to job satisfaction. This shows that the influence was high. This high influence was supported by the answers from several employees on the questions distributed through qualitative questionnaires which showed that the company gave reward and promotion to employees who excelled and this what motivated the employees at work. The better the motivation provided by the company, the higher the job satisfaction of employees at PT. Matsuo Precision Indonesia.

\section{References}

[1] F.J. Rauan and B. Tewal, Pengaruh Motivasi, Lingkungan Kerja Fisik Dan Stres Kerja Terhadap Kepuasan Kerja Karyawan Pada PT. Tropica Coco Prima Di Lelema Kabupaten Minahasa Selatan, Jurnal EMBA Vol. 7 No. 4 Juli 2019, Hal. 4681-4690 https://ejournal.unsrat.ac.id/index.php/emba/article/viewFile/25411/25069, 2014.

[2] Irawati, Sudarno, and D. Komardi, Pengaruh Motivasi Kerja, Komitmen Organisasi, Dan Budaya Organisasi Terhadap Kepuasan Kerja Dan Kinerja Guru Smp Negeri Pekanbaru, Vol 7 No 2: Procuratio : Jurnal Ilmiah Manajemen, http://www.ejournal.pelitaindonesia.ac.id/ojs32/index.php/PROCURATIO/article/view/442, 2019.

[3] F. Usman, "Pengaruh Lingkungan Kerja dan Kompensasi serta Komitmen Organisasi Terhadap Kepuasan dan Prestasi Kerja Pegawai," Jurnal Manajemen Vol. 11 (2), pp. 123-142, 2019.

[4] H.I. Permatasari and A.P. Prasetio, Pengaruh Stress KerjaTerhadapKepuasanKerjaPada PT Pikiran Rakyat Bandung: JurnalManajemen Dan Bisnis (Almana) Vol. 2 No. 1, April, 2018.

[5] Ramadanu, Dwipa, and S. Andri. "PengaruhKonflikKerjadanStresKerjaterhadapKepuasanKerja" (StudipadaKaryawan PT. Indah LogistikCabangPekanbaru)."Jurnal Online MahasiswaFakultasIlmuSosialdanIlmuPolitikUniversitas Riau, vol. 3, no. 2, Oct. 2016, pp. 1-13, 2016.

[6] I. B. W. Pratama. and A.A.A. Sriathi, "Pengaruh Stres Kerjadan Pemberdayaan Terhadap Kepuasan KerjaKaryawan di Prama Hotel," E-Jurnal ManajemenUnud, vol. Vol. 4 No. 11, no. 3565-3591, 2015.

[7] A. Jufri, S.N. Qomariah, and Ashlihah, "Pengaruh Motivasi, Kompensasi dan Lingkungan Kerja Terhadap Kepuasan Kerja Pegawai", Jurnal Pendidikan Ekonomi, Kewirausahaan, Bisnis dan ManajemenVol 3, No 2 (2019), 2019.

[8] I Ketut R. Sudiarditha, A.A.W.S Waspodo, N.A. Triani, "Pengaruh Lingkungan Kerja Dan Motivasi Kerja Terhadap Kepuasan Kerja Karyawan Pada Direktorat Umum Lembaga Pelayanan Publik Televisi Republik Indonesia", JurnalManajemen Volume XX, No. 02, Juni 2016: 278292, 2015.

[9] R. Putra, Nyoto, Suyono, E. Wulandari, "Pengaruh Motivasi, Pelatihan, Budaya Organisasi, Dan Komitmen Organisasi Terhadap Kepuasan Kerja Dan Kinerja Guru" Procuratio :JurnalIlmiahManajemen, Vol 7 No 3, 2019.

[10] Andi and Nyoto, " Pengaruh Buduya Organisasi, Motivasi Kerja, dan Komitmen Organisasi Terhadap Kepuasan Kerja dan Kinerja Karyawan pada PT Arta Boga Cemerlang Pekanbaru" Jurnal Akuntansi, Kewirausahaan, danBisnis Vol. 04 No. 01, 59-70, 2019.

[11] H. Mulyanto, and A. Wulandari, " Penelitian: MetodedanAnalisis, Semarang: CV Agung, 2010. 